\title{
Title:
}

Drivers and Impacts of Fisheries Scarcity, Competition, and Conflict on Maritime Security

Author names and affiliations:

Robert Pomeroy (Corresponding author)

University of Connecticut-Avery Point

Agricultural and Resource Economics/CT Sea Grant

Room 380, Marine Science Building

1080 Shennecossett Road

Groton, Connecticut 06340-6048 USA

Tel: 1-860-405-9215

Fax: 1-860-405-9109

robert.pomeroy@uconn.edu

John Parks

Marine Management Solutions, Honolulu, Hawaii, USA

Karina Lorenz Mrakovcich

United States Coast Guard Academy, New London, Connecticut, USA

Christopher LaMonica

United States Coast Guard Academy, New London, Connecticut, USA 


\section{Drivers and Impacts of Fisheries Scarcity, Competition, and Conflict on Maritime Security}

\section{Introduction}

Fishery scarcity, fueled by increasing fishing effort, overfishing, and user competition - along with other environmental stresses such as growing populations, marine pollution and coastal habitat modification - is an increasing global concern. It is now almost universally accepted that most of the nearshore fisheries in developing countries around the world are overfished and that fishing overcapacity is one of the leading causes of this overfishing [1,2]. Consequently, Earth's coastal waters are now experiencing increased levels of conflict and social unrest, affecting both regional security and environmental sustainability [3]. As the scale and degree of human conflict over remaining fisheries resources increases through time, this will limit the adaptive capacity of coastal communities to address the range of change drivers they face, impacting upon maritime security.

The concept of security significantly evolved during the last quarter of the 20th century. Traditionally, security has been defined to refer to military threats facing a state, of which such threats were mitigated through deterrence, power balancing, negotiation, or military action [4]. States' actions were predicated on the assumption that the international system was anarchic, and that they had to compete to survive [5, 6]. However, many security scholars have contested this narrow definition as failing to recognize the economic, societal, political and environmental dimensions of security and their interrelationship [7, 8]. This consequently led to a number of studies that have argued for a widening of the security agenda to include political, socioeconomic, and ecological security concerns [9], as well as other non-traditional threats to security, such as non-state actors. Non-traditional threats to security may be defined as "challenges to the survival and well-being of peoples and states that arise primarily out of nonmilitary sources, such as climate change, environmental degradation and resource depletion, infectious diseases, natural disasters, irregular migration, food shortages, people smuggling, drug trafficking, and other forms of transnational crime" [10]. These dangers are transnational in scope, defying unilateral remedies and requiring politically-, economically-, and sociallycomprehensive responses. Examples of non-traditional uses of military forces to address such transnational threats include multilateral peacekeeping forces, nation building, and regional stability operations.

Definitions of maritime security vary between the security and defense, transportation and shipping, and ocean policy and management sectors. Bueger [11] states that there is no international consensus over the definition of maritime security, however he highlights four dimensions of maritime security that are often shared between relevant sectors and actors: safety within the marine environment; economic development; national security interests and seapower; and human security. Germond [12] emphasizes the geopolitical dimension of maritime security, and the influence that this has on ocean governance and national defense, including by non-state actors.

Effective maritime governance and a smoothly functioning infrastructure ensure the viability of the global commons, whereas gaps in maritime security can enable the proliferation of security threats. In the absence of effective maritime governance, state and non-state actors can engage in 
or support piracy, illicit commerce (smuggling and human trafficking), illegal fishing, environmental pollution, and provide support for insurgency or acts of terrorism, while exploiting a country's territorial waters and exclusive economic zone. Poorly governed or ungoverned maritime spaces also invite undue influence from predatory states seeking to exploit a country's offshore fisheries, energy, or natural resources. Data and reporting on the full scope of maritime crimes remains poorly documented and largely uncoordinated, likely leading to a current underestimation of the true magnitude of the issue [13].

Increasingly, non-traditional threats to security are linked to the issue of natural resource scarcity [14]. Whether considering energy, food, or freshwater shortages, such resource scarcities exhibit common attributes. First, they share common drivers, or factors that influence and cause or exacerbate scarcity. Second, they are linked to each other through feedback loops, which create a major risk of unintended consequences when one scarcity issue is tackled without reference to other scarcity issues. Third, they have common impacts. That is, they disproportionately impact poor and fragile states, cause economic stress, and result in the potential for increased and strategically-targeted resource competition and conflict.

The purpose of this paper is to examine the linkages between fisheries resource scarcity, fisheries competition, and fishery conflict, and their cumulative impacts on peace and security within coastal nations. The paper reviews relevant literature and outlines a simplified analytical framework to highlight some of the key drivers and conditions underlying fisheries scarcity, competition, and conflict. The paper discusses the drivers, feedback loops, and impacts of fisheries resource scarcity, competition, and conflict on maritime security particularly from a Southeast Asian context; presents a theoretical discussion of how the numerous key drivers and conditions interact; and makes recommendations to address fisheries resource scarcity as it pertains to reducing conflict, promoting of civil stability, and strengthening maritime security. However, the factors discussed relating to fisheries scarcity, competition, and conflict are not unique to Southeast Asia, and in fact have been similarly observed in other parts of the world where the authors have worked, most notably in West Africa and the Gulf of Guinea, as well as the Gulf of Aden and the Arabian Peninsula.

\section{Drivers of Fisheries Scarcity}

Today, over 3 billion people worldwide rely on fish for at least $20 \%$ of their average per capita intake of animal protein. In some states, fish comprises more than $50 \%$ of dietary animal protein [15]. Fishing is the largest extractive use of wildlife in the world, and fisheries products are the world's most widely traded foods, with commerce dominated by the developing countries. In Southeast Asia, total dietary protein from fish is between 50 and $60 \%$ in Cambodia and Indonesia [16]. Fishing and fisheries-based commerce provide invaluable employment and cash income, create and grow local economies, and generate foreign exchange. Aggregate global capture fisheries statistics mask what one authoritative analysis has termed the "paradox of abundance and decline" [17] because the figures do not adequately portray the severity of overfishing in the coastal and inland waters of developing countries. Nor do the figures convey the changes taking place in the quality of the supply. 
Increasing scientific evidence indicates that marine, coastal, and freshwater ecosystems have been drastically altered over the past 50 years, reducing their productivity, resilience, and potential to continue providing social benefits in the future. Recent fisheries assessments [18, 19, 20] show reductions in the size and value of fish caught, and a decimation of key target species of fish, such as the large predators. In South and Southeast Asia, demersal fisheries have been fished down to 5-25\% of their unexploited levels [21]. Catch declines result in subsequent shifts to smaller and less-valuable species - the trend known as "fishing down the food web", moving from larger predatory species to smaller prey. Fishing and other anthropogenic disturbances alter and destabilize aquatic ecosystems, and increase their vulnerability to functional and productivity collapse or ecological transition. The erosion of the social-ecological resilience (defined as the capacity of linked social-ecological systems to absorb recurrent disturbances, such as storms and fluctuations in fish catch, so as to retain essential structures, processes and feedbacks [22, 23]) of coastal communities, especially those with a high dependence on the resource for food and livelihood, increases vulnerability.

When marine ecosystems and fish stocks are degraded or overexploited, the capacities of the sector to deliver on its food security, nutritional, and livelihood functions are limited or reduced. In spite of the important role that fisheries play in the national and local economies of many rebuilding, developing and transforming states, the fisheries sector faces a range of resource scarcity drivers that can be broadly categorized as weak governance, socioeconomic conditions, and ecosystem change [24, 25, 26, 27, 28]. Weak governance is one of the main causes of the present poor condition of fisheries. Factors characterizing weak governance in fisheries include (but are not limited to) corruption, lack of stakeholder participation, political will and capacity, weak institutional capacity and capabilities, poor enforcement, and inadequate information. In a broader sense, several factors can impede a country's ability to govern its maritime spaces and resources. These factors include shortfalls in security capacity, conflicting authorities, mismatches between resources and authorities, inadequate or nonexistent laws, ineffective enforcement, ineffective judicial process, and corruption of governing officials [29].

A number of socioeconomic factors - including poverty, limited livelihood options, globalization of trade and market access, technological advances, population growth, human health, political marginalization, wealth disparities, food insecurity, lack of public health and educational services, and ethnic and gender inequity - constrain improved fisheries management and are root causes of some overfishing problems. Unsustainable fishing practices result in direct changes to the structure and composition of aquatic and marine ecosystems, changes that make them less resilient and less able to produce food for millions of people. There are also a number of indirect human activities that affect the biodiversity and productivity of fisheries ecosystems including pollution from land-based and maritime (e.g., hydrocarbon production) sources, habitat degradation and destruction and, from a longer-term perspective, anthropogenic ocean and climatic changes.

\section{Feedback Loop of Fisheries Scarcity, Competition, and Conflict}

Since the 1980's, an increasing volume of literature has assessed the implications of environmental degradation for political systems, with particular emphasis on the potential for resource-based scarcity and conflict $[30,31]$. Most studies have focused on renewable resources 
in terrestrial systems, such as freshwater, timber, and fertile land, however recent trends have demonstrated the significant need to increase our understanding of how scarcity and resource degradation in marine ecosystems may affect political institutions and expedite conflict. Studies suggest that where there exists a high degree of local dependency on natural resources to meet basic nutritional requirements and sustain livelihoods, the availability of food and water may serve as an independent variable that correlates with both the degree of civil unrest and regional political stability [32]. While environmental security is rarely the single causal factor in civil unrest or political instability, the correlation of these outcomes with resource scarcity renders it a critical element in monitoring global stability and region specific peace and development. More importantly, if marine resource scarcity does contribute to civil unrest, are there management approaches that can be used to mitigate this influence?

The 'overharvesting' of the majority of the world's coastal fisheries is resulting in the reduction or collapse of critical fishery populations, leading to increased levels of poverty, economic stress, conflict and escalating violence among the various competing user groups in the coastal waters. A complex, feedback cycle is created in this situation, whereby a growing population with shrinking economic opportunities or access to land lead to an increase in both the number of people living in the coastal zone dependent on fishery resources as well as the number of fishers. The resulting increased fishing pressure leads to further fishery population declines, thereby increasing competition both between fishers and among levels of fishing operation (e.g., smallscale/artisanal versus commercial; foreign fishing fleets versus local fleets) over remaining stocks $[33,34]$. The local result is reduced income levels and food security, driving the selection of more destructive and over efficient fishing technologies in the 'rush' to catch remaining stocks, thereby further depleting fishery populations.

Such competition is not always passive in nature. These factors cumulatively lead to higher rates of human conflict and violence, both at-sea and on-land (Table 1). These conflicts include violence between fishers operating at the same scale, violence among fishers operating at different scales, maritime crime, armed conflict, and civil unrest. As presented in Table 1, each of these fisheries-related conflict type can be associated with particular drivers. For example, competition between small fishers due to coastal crowding in Vietnam has led to increasing conflict for declining fisheries. Competition between municipal and commercial fishers in the Philippines, coupled with the increased availability and reduced cost of small arms and munitions, has led to a trend in armed fishing operations and heightened civil unrest. The division of ownership of the sea, through redefined political boundaries or through such management approaches as marine protected areas, increases competition and conflict over remaining resources, with fishers becoming, at least legally, ever more restricted in their movements. This is particularly problematic because the new boundaries rarely take into account the traditional fishing grounds of local fishers, who have to adapt to the new rules or face the consequences. Liss [35] reports that one of the driving forces of illegal fishing is overfishing, as fishers whose traditional fishing grounds are overfished do venture into other waters to supplement their catch, leading to increased competition and conflict. The increased incidence of competition and conflict arising from overfished coastal fisheries may also correlate with other transnational threats, particularly the illegal trafficking of goods (e.g., small arms; narcotics) and people (e.g., slaves) and piracy, namely in the form of at-sea robbery, kidnapping and ransom of a vessel's crew, and oil theft and transfer ("illegal oil bunkering") [13, 36, 37, 39, 40, 41, 42, 43, 
44, 45, 46, 47]. Williams [38] reports that in addition to poaching the fish stocks of other states, illegal fishing is frequently associated with other illegal activities such as smuggling of fish, fuel and people, piracy and kidnapping. Liss [35, 48] and Bateman [49] report on the links between piracy and traditional fishers in Southeast Asia, who are often driven to engage in piracy due to fisheries scarcity. These fishers engage in petty theft from ships at anchor or in port in Indonesia, the Philippines, and Vietnam and board vessels, such as merchant ships and fishing vessels at sea, to steal cash, valuables, and fish. Fisheries scarcity and the increased competition for fish leads to decline in wealth and livelihoods, creating dissatisfaction and fueling insurgency and insecurity, which are a determinant to the international community. In the Southern Philippines, fishers are engaging with known terrorist organizations, such as the Abu Sayyaf group, in increased maritime attacks on both land and sea. Security concerns also exist regarding the illegal production and trafficking of fertilizer-based bombs to supply dynamite fishers operating in Southeast Asia, and the potential for such materials to be used by insurgency or separatist movements or in acts of terrorism.

(Table 1 here)

This destructive cycle leads to a pattern of self-reinforcing "fish wars" resulting in deteriorating social, economic and political conditions, including poverty, food insecurity, and loss of income and livelihoods. The linkages among such drivers and conditions can be presented within simplified representation of this "fish wars" cycle as they relate to three central elements: the degree of fisheries resource scarcity, the level of fisheries resource competition over remaining stocks, and the level of human conflict between fishers and with other stakeholder groups (Figure 1). Fisheries resources scarcity, competition, and conflict may erode the social-ecological resilience of coastal communities who have a high dependence on coastal ecosystems to meet daily food and household income needs. Fishers' livelihoods are threatened, for example, by commercial fishing operations whose scale and technology make it impossible to compete against. While it impossible to quantify the number of fishers who have engaged in maritime crimes, experts agree that many small fishermen have engaged in these activities as socialecological resilience of their communities has decreased [37]. Such instability is thought to fuel political instability and civil unrest, thereby acting as a destabilizing risk factor to national, regional and global security concerns. Understanding the potential contributing influences of fisheries scarcity, competition, and conflict on regional stability and peace and order is of particular interest to national defense forces (e.g., coast guard) and international security coalitions (e.g., United Nations peacekeeping missions). The improved understanding of such linkages may help to identify and predict regional instability and civil unrest.

Figure 1 presents a number of factors that influence each of the three central elements of fisheries scarcity, level of competition, and level of conflict. Within the feedback loop, some of the factors within one of the central elements can drive (cause or exacerbate) and/or negatively impact other factors associated within the other two central elements, as well as be the result (consequence) of those other central elements. The contributions of each of the three central elements in driving the feedback loop are discussed below.

(Figure 1 here) 


\subsection{Contributions from Fisheries Scarcity within the Fish Wars Cycle}

Within the fish wars cycle, fisheries scarcity is driven through a suite of biological, social, and governance factors (see Figure 2). On the biological side, a number of threats negatively influence and create change within coastal and marine ecosystems, including: the introduction of land-based pollution; the introduction of marine debris; reductions to resident marine fish populations; the loss of marine biological diversity; and ocean and climatic change. Coastal and marine habitat degradation and destruction, the alteration of marine community composition and trophic relationships, and the use of destructive fishing methods or gear types all contribute to the loss of marine biodiversity. Unsustainable rates of fishing, fishing overcapacity, and illegal, unreported, and unregulated (IUU) fishing all reduce resident fish populations and alter natural size class distributions. Ocean acidification, sea surface temperature warming, and sea level rise all contribute to observed oceanic and climatic changes within the ecosystem $[50,51]$.

On the social side of drivers relating to fishery scarcity, a number of factors influence the socioeconomic conditions, including: human population growth; poverty; food insecurity; economic marginalization and wealth disparities; political marginalization; ethnic and gender inequities; and technological advances. Limited livelihood options and a lack of public services, such as health and education, all drive poverty rates. Trade globalization, limited market access, and a lack of access to capital and credit all drive economic marginalization and wealth disparities.

On the governance side of drivers relating to fishery scarcity, a number of factors negatively impact fishery resource governance, including: ineffective enforcement; lack of public participation in resource decision-making and governance; weak institutional capacity of fishery management authorities and agencies; inadequate information to accurately and adaptively manage fishery resources; corruption; and organized crime. Graft, corrupt civil servants (including law enforcement), and corrupt elected officials and decision-makers all drive the extent of corruption influencing how fishery resources are managed and governed. Insufficient maritime security presence or capabilities, ineffective judicial process, and under-developed law enforcement systems all negatively influence the effectiveness of fisheries enforcement efforts. An inadequate legal framework, including fishery resource laws, rules, and regulations, as well as conflicting resource management authorities and regulations all contribute to weak institutional capacity to govern marine fisheries.

Factors within the ecosystem change, socio-economic conditions, and resource governance not only directly influence fisheries scarcity, but can also influence one another. For example, poverty and food and economic insecurity (all socioeconomic conditions) may drive the level of corruption (resource governance) as well as unsustainable and illegal fishing that reduce fish populations (ecosystem change), all driving increasing fisheries scarcity. Cumulatively, these fisheries scarcity factors exacerbate the level of competition over remaining fish stocks, in turn driving the type and levels of fisheries conflicts.

(Figure 2 here)

3.2 Contributions from Level of Competition within the Fish Wars Cycle 
Within the fish wars cycle, the level of competition over available fishery resources is driven through a suite of factors relating to increasing fishing pressure and efficiency, coupled with multiple (and often increasing) scales of fishing operations (see Figure 3). In some cases, increasing limitations or restrictions to fishing grounds also drives the level of competition.

Relating to increasing fishing efficiency and pressure, a number of factors drive increased competition over available fishery resources, including: the use of highly efficient, but legal, gear types; the use of destructive fishing practices and gear types (usually illegal); an increased number of fishers; and an increased demand for seafood and marine products. The global migration trend of people from remote, rural areas into the urbanized or developing coastal zone, as well as the entry of people into fishing as a livelihood, drives increasing numbers of fishers, and thereby, fishing pressure. Both an increasing demand by foreign (importing) countries for seafood products (export markets), as well as an increasing demand domestically within local and national seafood markets, drives an overall increasing demand for seafood being observed worldwide. Because local seafood products represent the primary or significant source of protein to meet the dietary needs of residents within many developing coastal nations, this drives increasing domestic seafood demands. Prolonged life expectancy and decreased infant mortality exacerbate human population growth, which further drives the level of domestic seafood demand, thereby raising fishing pressure.

In terms of fishing operations, both the type and scale of operations directly influence the level of competition over available fisheries. The globalization of seafood markets drives both the domestic and foreign fishing fleet capacities. This includes the number of commercial fishing vessels operating, as well as the number of commercial fishing licenses issued. This increase includes both medium- to large-scale fishing operations, including modern-day seafood factory vessels that land, process, package, and store seafood products at sea. Likewise, an increasing number of both domestic and foreign small-scale fishers, largely operating within coastal waters, drives the level of competition over available resources. The rising number of subsistence and artisanal fishers further increases resources competition.

During the past 50 years, marine resource management efforts have grown to include the declaration of closed areas (marine reserves), limited access areas, and managed areas regulated and/or zoned for multiple uses beyond fishing (e.g., marine protected areas). Non-fishery users of waters found within fishing grounds include: shipping and transportation; recreation and tourism; oil and gas exploration and seabed drilling; seabed mining; and defense and military operations. Such non-fisheries users compete over and may limit or inhibit traditional levels of access to fishing grounds. Increasing limitations or prohibitions over traditional fishing grounds pushes fishing effort into areas where fishing is still allowed, concentrating fishing users and effort, and thereby increasing the level of competition over available resources. In addition, some coastal nations have contested maritime boundaries with neighboring countries, further increasing the level of competition over contested fishing grounds.

Factors within the increasing fishing efficiency and pressure, fishing operation scales, and fishing ground limitations not only directly influence the level of fisheries competition, but can also influence one another. For example, the designation of new marine reserves, coupled with new zoning for non-fisheries uses, may in turn drive fishers to use destructive and illegal fishing 
practices in order to increase their yield within the waters where they are still allowed to fish, as well as fish illegally within closed areas and non-fishery zones. Similarly, an increasing domestic seafood demand may result in an increased level and scale of small-scale commercial fishing operations, while at the same time an increasing foreign demand drives growth in foreign commercial fishing fleet sizes and presence. Increased fishing pressure and efficiency, coupled with increasingly limited fishing grounds and increasing scale and number of fishing operations all drive increasing fisheries completion levels. Cumulatively, these competition level factors exacerbate the type and levels of fisheries conflicts, while both drive increased fisheries scarcity.

(Figure 3 here)

\subsection{Contributions from Level of Conflict within the Fish Wars Cycle}

Within the fish wars cycle, the level of fisheries conflict is driven through a suite of factors relating to the levels of marine resource user group violence and maritime crime, coupled with the presence and level of societal conflict, including civil unrest and/or armed conflict (see Figure 4).

The level of violence between marine resource stakeholders, and particularly fishery user groups, is a key contributing factor to the overall level of fisheries conflict. The level of violence among fishers (i.e., fisher-on-fisher violence, across scales) and between user groups (e.g., between a fisher and recreation user, or between two non-extractive user groups) both contribute to overall user group violence levels. The presence and extent of maritime crime within or adjacent to the fishing grounds further contributes to the level of fisheries conflict. Piracy (including kidnapping and ransom, robbery at sea, and oil bunkering or theft) and illegal trafficking (particularly of narcotics, wildlife and/or animal products, small arms, and humans) both are conspicuous and common forms of maritime crime.

In some nations and regions, the level of user group violence and maritime crime is further exacerbated by background societal issues, most notably civil unrest (including political instability, food and livelihood or economic insecurity, religious and/or ethnic conflict, and insurgency) and armed conflict (intrastate conflict or war, interstate conflict/civil war, and terrorism).

Factors relating to violence, crime, civil unrest, and armed conflict not only directly influence the level of fisheries conflict, but can also influence one another. For example, political instability that leads to civil war can disrupt or devastate national and local economies, driving rates of maritime crime and increase violence from armed forces and local militias on small-scale fishers. Likewise, religious- or ideologically-driven conflict can spur insurgency and terrorism, funded through transnational maritime crime (e.g., trafficking of small arms for armed conflict; trafficking of narcotics to fund armed conflict), resulting in increased violence between coastal residents and between fishers of different faiths or belief systems. Cumulatively, such conflict factors can escalate both the level and frequency of fisheries and/or maritime-related conflicts, spurring both increased competition and fisheries scarcity. For example, the costs of sustaining civil unrest and insurgency may spur rates of both piracy and illegal trafficking, as well as 
encourage illegal fishing and fisher-on-fisher violence, cumulatively increasing the level of fisheries conflict while also reducing fish stocks and driving fisheries scarcity.

(Figure 4 here)

\section{Discussion and Recommendations}

The responses to addressing the "fish wars" cycle of fisheries scarcity, competition, conflict and their negative impacts on overall maritime security have been largely singular in approach, targeting a specific issue rather than addressing multiple issues through a coordinated and integrated approach. In addition, they have often targeted the impact, such as IUU fishing, rather than the driver, such as lack of livelihoods, or try to break the feedback loop. Relating to the dynamic relationship between resource scarcity, competition, and conflict within the "fish wars" cycle, the following recommendations are offered to address fisheries management as it pertains to reducing conflict, enhancing maritime security, and promoting civil stability.

- $\quad$ Strengthening fisheries governance: Restructuring and strengthening fisheries governance (and in a broader sense, maritime governance; see [29]) presents a solution [52, 53, 54, 55]. Governing for a resilient social-ecological system should prevent the fishery from failing to deliver benefits by nurturing and preserving ecological, social, economic and institutional attributes that enable it to endure, renew, and reorganize. Fisheries should be considered as systems in which social systems and ecological systems are, in fact, linked. The establishment of institutions, policies, and processes through which management may be realized is fundamental to effective fisheries governance. Improvements in fisheries governance can be undertaken at local, national, regional, and international scales, including the need to support greater capacity and capabilities. Improving fisheries governance is less a centralized process for "problem solving" than a collaborative dialogue among public and private partners that interact to think about, plan, promote, aid, and benefit from improved fisheries governance. In a broader sense, maritime governance reform can address littoral security challenges that arise from a variety of social, security, and economic factors and hinder a country's ability to govern itself [28]. One way forward that emerges is the need to be inclusive in governance, and the need to share in the responsibility of governance. Thus, the secondary challenge is building and strengthening the social-ecological resilience of coastal nations and communities to the many impacts of fisheries resource scarcity and to end the destructive cycle of "fish wars." This perspective calls for a new way of managing fisheriesspecifically, ecosystem-based approaches. An ecosystem-based approach to fisheries management (EAFM) is geographically specified fisheries management, an approach that takes account of knowledge and uncertainties about and among living marine resources, their habitat, and human components of ecosystems, and strives to balance diverse societal objectives $[56,57]$. EAFM supports increased stakeholder participation in management, co-management, improved information, and improved institutional capacity. The importance of political will and political capacity in determining the quality of fisheries management is central to strengthening fisheries governance. Increased, meaningful engagement by the private sector is necessary for EAFM to succeed. Fisheries will experience significant impacts from climate and ocean change over coming 
decades, both directly through changes in the physical and chemical environment (e.g. rising ocean temperatures and decreasing $\mathrm{pH}$ ), and indirectly through changes to habitat and food supply. Climate and ocean change concerns should be incorporated into all fisheries management and EAFM planning processes and plans.

Recent management experience $[58,59,60,61]$ illustrates how centralized authorities that use a command-and-control approach to marine resource management have not been effective at addressing marine resource scarcity, enforcing existing rules and regulations, or resolving user conflicts over fisheries extraction. This has led to a call for new governance and institutional arrangements to manage coastal resources and marine fisheries. One solution, with potential to address multiple drivers impacting fisheries, is the use of collaborative management (co-management), a governance partnership in which government agencies share the responsibility and authority for making decisions about the management of a fishery with fishers and fishing communities. Such fisheries co-management approaches are demonstrating potential for intervening on the negative "fish wars" cycle by reducing user conflicts while also building capacity for improved fisheries management, strengthening food security, and empowering local livelihoods. Such collaborative governance approaches are giving resource users and local citizen groups a greater voice and more opportunity to participate in resource management decisions and local economic development [62]. People are empowered to make adaptive and informed marine resource management decisions that are appropriate to the sitebased context and functioning of their community's social-ecological system.

During the past two decades, fisheries co-management has been tested throughout many of the nations in Southeast Asia. Early experience and lessons learned in doing so suggest that taking a co-management approach to intervene on the "fish wars" cycle can also address maritime security concerns. For example, in San Salvador Island in the Philippines, a fisheries co-management arrangement was able to resolve violent and nonviolent conflicts between local fishermen who utilized traditional fishing gear and new migrants to the Island who were releasing potassium cyanide on coral reefs to stun and collect live marine ornamental fish to supply the lucrative international aquarium trade [63]. Further, a quantitative analysis undertaken by some of the authors between 2003 and 2005 within selected coastal communities throughout Indonesia, the Philippines, Thailand, and Vietnam with and without fisheries co-management arrangements indicate that the presence of co-management arrangements are correlated with lower levels of resource user conflict and local peace and order [60,61]. This analysis has also indicates that where marine resource conflicts are reduced, local food security improves [60, 61]. 
- $\quad$ Addressing the root causes of fisheries scarcity and fisheries conflict: Many of the solutions to fisheries scarcity and maritime security threats lay outside traditional government responses, which often focus on the problem rather than the root causes, and are often not easy to implement. There is no single, simple solution to end the "fish wars" cycle. The complexities of fisheries make the use of any single approach in isolation improbable. The only feasible solution may be one based on a coordinated and integrated approach involving an increased focus on people and communities. This multilevel approach implies an increased focus on people-related solutions and on communities, on strengthening and building human capital, and on strengthening and building effective governance mechanisms. Having alternatives to fishing that locally generate income and food can reduce the pressure to exploit local resources and engage in criminal activities. When fishers and communities have few if any economic alternatives, it will be difficult to institute effective fishery management involving constraints on fishing, since the impacts of such decisions may be unacceptably severe. Efforts to develop livelihood opportunities must not be seen as a panacea to solving fishery problems. Nevertheless, the broadened perspective inherent in improved fisheries management, such as EAFM, requires a holistic approach to addressing the needs of individuals, households and communities and should support their development of sustainable portfolios of livelihood sources. Although the problem of fishing overcapacity is well recognized and relatively easy to analyze, it remains one of the most intractable problems in fisheries management. Issues of overcapacity and unsustainable resource use cannot be isolated from poverty, unemployment, and declining quality of life in fishing communities, because overfishing most directly affects highly resource dependent populations such as fishing households. Although many of the fishing capacity issues are demonstrably national issues and lie within the jurisdiction and responsibility of individual states, there is a clear need for a regionally coordinated approach.

- $\quad$ Addressing lack of political will: Factors which hinder the ability of government agencies to address fisheries scarcity and maritime security threats include (but are not limited to) corruption, conflicts of interest, lack of political will, inadequate resources (physical, human and financial) available for fisheries management, poor enforcement, lack of professionalism, and lack of a clear vision for the fisheries. Lack of political will on the part of political and judicial leaders and bureaucrats is cited as the most frequent reason for unsuccessful governance and economic reform efforts. Experience has shown that local champions of fishery management can affect moderate progress on this complicated issue if they use community networks to engage in enforcement of fishery policies. In addition, there is a need to focus on building institutional capacity at the national and local levels to deal with policy development and regulation.

- Engagement with the fisheries private sector: The primary private sector interests regarding fisheries management are focused around business growth (i.e., maximizing profit and/or securing new markets) and economic (i.e., increased competitiveness and leverage, and/or market viability). Nearly all private sector stakeholders have inherent, long-term (i.e., multigenerational) financial interest in maintaining and growing the fishing industry, often supported through long-term family business interests (including non-fishery enterprises) and a vision of business growth. The private sector tends to be 
well organized in each country through existing local (sub-national) and national fisheries associations and federations of associations. Many of the private sector companies are global players in the fishing industry, and are regularly exposed to various debates about sustainable seafood and complex proposals to ensure product traceability. However, as they explain, at the end of each day the simple calculus that they must face in order to stay in operation is having sufficient raw materials sourced at a low enough cost in order to meet present demand (orders placed) at a fair price; thus providing a margin through which they can continue to exist, and ideally (but not typically) grow. The private sector do not seek out engagement as they often feel that they are targeted as the "cause of the problem" or the "bad guy" by conservation and environmental advocacy groups, rather than as a strategic partner who must be included as part of the solution. In both Indonesia and the Philippines, commercial fishers have recently expressed their growing concern regarding fisheries scarcity, competition, conflict and maritime security [64]. As a result, commercial operators report having no choice but to adapt, often working together in groups (coordinated through associations) to quietly prepare for inevitable tactical engagement and self-defense measures at sea. Coupled with concerns regarding the atsea illegal trafficking of humans, narcotics, and small arms, commercial operators report that maritime security is an increasing issue, and one that elected officials and the general public are poorly aware of and/or equipped to address. As a result, fisheries associations are becoming de facto forward operating bases for groups of commercial fishing operations, through which the latest at-sea intelligence, security and self-defense measures, and tactical strategy and navigational and operational adaptation techniques are shared among association members.

\section{Conclusions}

Increasingly, non-traditional threats to national security are linked to the issue of natural resource scarcity. Whether considering energy, food, or water shortages, such natural resource scarcities exhibit common attributes. First, they all share common drivers, or factors that influence and cause or exacerbate scarcity of the resource. Second, they are linked to each other through feedback loops, which create negative, often unintended consequences when one scarcity issue is tackled without reference to other scarcity issues. Third, they have negative socioeconomic impacts. They disproportionately impact poor and fragile states, exacerbate economic stress and social hardship, and compound resource competition and conflict. An overriding challenge is to address negative feedback cycles between resource scarcity, competition, and conflict that influences or threatens national or regional security and natural resource sustainability.

In analyzing and clarifying how the fish wars cycle operates, we can improve our understanding of the connections and degree of linkages between factors within the fisheries scarcity, level of completion, and level of conflict feedback cycle. For example, declining socioeconomic conditions (e.g., food insecurity) that directly relate to fisheries resource scarcity may in turn spur increased levels of fisheries competition over remaining marine resource populations, in turn driving increased levels (type and frequency) of human conflict. At the same time, increasing levels of fisheries competition (e.g., increasing fishing pressure) and conflict (e.g., piracy) may negatively impact the level of food security. While this paper presents a theoretical 
discussion of how the numerous factors relating to how the key elements interact within the fish wars cycle, we suggest that a systematic investigation into the degree of influence between such linked factors in the model would help fisheries managers both better understand which 'threads' of linked factors to strategically intervene upon, as well as monitor and 'predict' how changes within such threads of linked factors may drive fisheries scarcity, competition, and conflict within managed stocks

In the case of fisheries management, effective (defined as a principle of good governance in which the governing body should strive to produce quality public outputs, including services delivered to citizens, at the best cost, and ensure that outputs meet the original intentions of policymakers [65]) maritime governance and a smoothly functioning infrastructure help to encourage the viability of effectively-managed ocean commons and marine managed areas, whereas gaps in fisheries management are known to enable the proliferation of security threats and complicate maritime security. In the absence of effective maritime governance and enforcement, state and non-state actors are able to engage in or support a country's territorial waters and exclusive economic zone in order to engage in piracy, illegal fishing, and/or illegal maritime commerce. Poorly governed or ungoverned maritime spaces also invite undue influence from predatory states that seek to exploit a country's offshore fisheries, energy, or natural resources. For example, cross-border illegal fishing off the coasts of many Southeast Asian nations by actors from North Asia not only places a hardship on local populations who depend on fish as their primary source of dietary protein, but also creates broader instability in the region. Throughout coastal nations of Southeast Asia, IUU fishing exacerbates diplomatic, territorial, and military tensions, while also decreasing food, economic, and environmental security and perpetuating human rights abuses. In order to address such transnational threats, a wide range of actors must work together to deeply investigate and analyze such linkages in order to collaboratively design appropriate and targeted management interventions that can be tested, refined, and deployed locally, nationally, and regionally. Such actors should not only include national government agencies, fishery resource managers, and maritime enforcement authorities, but also local communities, private companies, national defense forces, human rights advocates, and non-governmental organizations. Benefits of maritime security reform that recognize and address linked, non-traditional threats include enhanced livelihoods and food security as well as freedom from fear [66].

\section{Acknowledgements}

The authors would like to thank the US Coast Guard Academy and the University of Connecticut Storrs Agricultural Experiment Station. The authors would like to thank the U.S. Department of Defense, U.S. Department of Homeland Security and the U.S. Agency for International Development for their support of a variety of research projects relating to fisheries and coastal and marine resource management during the past two decades within Southeast Asia and Africa that enabled the authors to share similar observations and together analyze and develop the fish wars cycle presented in this paper. The authors would also like to recognize and thank three anonymous reviewers who provided useful feedback and suggestions on earlier drafts of this paper. 


\section{References}

[1] S. Garcia, I. De Leiva Moreno, Trends in World Fisheries and Their Resources in The State of the World Fisheries and Aquaculture. Rome: FAO. 2000.

[2] Coastal Resources Center, Fisheries Opportunities Assessment. Kingston and Miami: Coastal Resources Center at the University of Rhode Island and Florida International University. 2006.

[3] M.J. Williams, The Transition in the Contribution of Living Aquatic Resources to Food Security. Washington, D.C.: International Food Policy Research Institute. 1996.

[4] H.J. Morgenthau, K. Thompson, Politics among Nations, 6th ed. McGraw-Hill, New York. 1985.

[5] H. Bull, The Anarchical Society. Columbia University Press, New York. 1977.

[6] B. Buzan, Ø. Waever, J. de Wilde (Eds). Security: A New Framework of Analysis. Boulder, CO: Lynne Rienner. 1998.

[7] R. Bates, Prosperity and Violence: The Political Economy of Development. W.W. Norton \& Co., New York. 2001.

[8] L. Elliot, Regional Environmental Security: Pursuing A Non-Traditional Approach, in A.T.H. Tan, J.D.K. Boutin, (Eds) Non-Traditional Security Issues in Southeast Asia, Singapore: Institute of Defence and Strategic Studies, 2001. 438-467.

[9] N. Tschirgi, M.S. Lund, F. Mancini, Security \& Development: Searching for Critical Connections. Lynne Reiner, Boulder, CO. 2005

[10] M. Caballero-Anthony, Nontraditional Security and Multilateralism in Asia: Reshaping the Contours of Regional Security Architecture? Policy Analysis Brief. The Stanley Foundation, Muscatine, IA 2007.

[11] C. Bueger Learning from piracy: future challenges of maritime security governance, Global Affairs, 1:1, (2015) 33-42

[12] B. Germond, The geopolitical dimensions of maritime security. Marine Policy, 54, 2015, 137-142.

[13] OBP (Ocean Beyond Piracy). The State of Maritime Piracy in West Africa. 2014. http://oceansbeyondpiracy.org/west-africa

[14] A. Evans, Managing scarcity: the institutional dimensions. Presentation at DPA Nontraditional Security Threats Program, New York, 25 August. Center on International Cooperation, New York University. 2009. 
[15] FAO (Food and Agriculture Organization of the United Nations) The State of World Fisheries and Aquaculture 2012. FAO, Rome. 2012. 209pp.

[16] HLPE. Sustainable fisheries and aquaculture for food security and nutrition. A report by the High Level Panel of Experts on Food Security and Nutrition of the Committee on World Food Security, Rome, 2014.

[17] World Humanity Action Trust. Governance for a Sustainable Future. II Fishing for the Future. Report. London. 2000.

[18] D. Pauly, V. Christensen, J. Dalsgaard, R. Froese, F. Torres. Fishing down marine food webs. Science, 279, 1998, 860-63.

[19] D. Pauly, V. Christensen, S. Guanette, T.J. Pitcher, U. R. Sumaila, C.J. Walters, R. Watson, D. Zeller. Towards sustainability in World Fisheries. Nature, 418, 2002,689-95.

[20] R.A. Myers, B. Worm. Rapid worldwide depletion of predatory fish communities. Nature 423, 2003, 280-3.

[21] I. Stobutzki, G. Silvestre,L. Garces, Key issues in coastal fisheries in South and Southeast Asia, outcomes of a regional initiative. Fisheries Research 78, 2006, 109-118.

[22] C. Holling, Resilience and stability of ecological systems. Annu. Rev. Ecol. Syst. 4, 1973, $1-8$.

[23] B. Walker, C. S. Holling, S. Carpenter, A. Kinzig. Resilience, adaptability and transformability in social-ecological systems. Ecol. Soc. 9(2), 2004.

[24] M. Torell, A. Salamanca, Institutional issues and perspectives in the management of fisheries and coastal resources in Southeast Asia. Penang, Malaysia: ICLARM - The World Fish Center and Swedish International Development Cooperation Agency. 2002.

[25] E. Whittingham, J. Campbell, P. Townsley. Poverty and Reefs. Paris: United Nations Educational, Scientific and Cultural Organization. 2003.

[26] L. Burke, E. Selig, M. Spalding, Reefs at risk in Southeast Asia. Washington, DC: World Resources Institute. 2002.

[27] Coastal Resources Center. Fisheries Opportunities Assessment. Coastal Resources Center, University of Rhode Island, and Florida International University. 2006. 104p.

[28] E. Allison, A. L. Perry, M-C. Badjeck, W. Neil Adger, K. Brown, D. Conway, A. S. Halls, G. M. Pilling, J. D. Reynolds, N. L. Andrew, N. K. Dulvy. Vulnerability of national economies to the impacts of climate change on fisheries. Fish and Fisheries, 10, 2009, 173-196. 
[29] J. Sandoz, Maritime Security Sector Reform. Special Report 306. U.S. Institute of Peace, Washington, DC. 2012.

[30] N. Myers, Ultimate Security: The Environmental Basis for Political Stability. W.W. Norton, New York. 1993. 308 pp.

[31] D. Buckles, (Ed.) Cultivating Peace: Conflict and collaboration in natural resource management. International Development Research Centre, Ottawa, Canada. 1999.

[32] E. Bennett, A. Neiland, E. Anamg, P. Bannerman, A.A. Rahman, S. Huq, S. Bhuiya, M. Day, M. Fulford-Gardiner, W. Clerveaux. Towards a better understanding of conflict management in tropical fisheries: evidence from Ghana, Bangladesh and the Caribbean. Marine Policy. 25, 2001, 365-376.

[33] M. Bavinck, Understanding fisheries conflicts in the South-a legal pluralist perspective. Society and Natural Resources: An International Journal. 18(9), 2005, 805-820.

[34] M. Warner, Conflict Management in Community-Based Natural Resource Projects: Experiences from Fiji and Papua New Guinea. ODI Working Paper No. 135. Overseas Development Institute (ODI), London. 2000. 40 pp.

[35] C. Liss, Oceans of crime: maritime piracy and transnational security in Southeast Asia and Bangladesh. Institute of Southeast Asian Studies, Singapore. 2011.

[36] UNODC (United Nations Office on Drugs and Crime) Transnational Organized Crime in the Fishing Industry. United Nations, Vienna. 2011. 140pp.

[37] A. McCauley, Pirates in Southeast Asia: The world's most dangerous waters. Time magazine. 2014. Time.com/piracy-southeast-asia-thailand-singapore-indonesia-malacca-straitorapin-4. Accessed 22 September 2014

[38] M. J. Williams, Will new multilateral arrangements help Southeast Asian states solve illegal fishing? Contemporary Southeast Asia. Vol. 35(2), 2013, 258-83

[39] C. Jasparro, Environmental Threats to Security, Stability, and U.S. Interests in Southern Africa: Opportunity Knocks - Time for a Comprehensive Region Defense Environmental International Cooperation and Environmental Security Assistance Strategy. Institute for National Security Studies Research Paper. United States Air Force Academy, Colorado Springs, Colorado. 2009.

[40] C. Bueger, J. Stockbruegger, S. Werthes, Pirates, Fishermen and Peacebuilding: Options for Counter-Piracy Strategy in Somalia, Contemporary Security Policy, 32:2, 2011, 356-381

[41] B.B. Solarin, O. A. Ayinla. Together Against Pirates: Sea Piracy and Armed Sea Robbery are Major Constraints to Capture Fisheries in the Waters of Nigeria. Samudra Report 62. International Collective in Support of Fish Workers, India. 2013. 
[42] Atlantic Council. Advancing U.S., African, and Global Interests: Security and Stability in the West African Maritime Domain. The Michael S. Ansari African Center and the On the Horizon Project. 2010. 78 pp.

[43] J.B. Asuni, Blood oil in the Niger Delta. Special Report 229. August. United States Institute of Peace. Washington DC. 2009.

[44] C. LaMonica, J.S. Omotola, Horror in Paradise: Frameworks for Understanding the Crises of the Niger Delta of Nigeria. Durham, NC: Carolina Academic Press. (2014). 303pp

[45] M. Valencia, M. The Politics of Anti-piracy and Anti-terrorism Responses in Southeast Asia. in Piracy, Maritime Terrorism and Securing the Malacca Straits, edited by Graham Gerard Ong-Webb. Singapore: Institute of Southeast Asian Studies. 2006. 84-102

[46] US ICE. Human trafficking: a global problem. United State Immigration and Customs Enforcement, Washington DC. 2014.

[47] UNODC. Transnational organized crime in East Asia and the Pacific: a threat assessment. United Nations Office on Drugs and Crine, Regional Office for Southeast Asia and the Pacific, Bangkok. 2013. 173pp.

[48] C. Liss, New actors and the state: addressing maritime security threats in Southeast Asia. Contemporary Southeast Asia. 35(2), 2013. 141-162

[49] S. Bateman, Sea piracy: some inconvenient truths. Disarmament Forum. 2, 2010, 13-24.

[50] S. Kaye, Climate change and maritime security. Chapter 7 in Warner, R and C. Schofield, Climate change and the Oceans: gauging the legal and policy currents in the Asia-Pacific and beyond. Edward Elgar, Northhampton, MA, USA 2012.

[51] C. Rahman, The implications of climate change for maritime security forces. Chapter 8 in Warner, R and C. Schofield, Climate change and the Oceans: gauging the legal and policy currents in the Asia-Pacific and beyond. Edward Elgar, Northhampton, MA, USA 2012.

[52] M. Bavinck, R. Chuenpagdee, M. Diallo, P. van der Heijden, J. Kooiman, R. Mahon, S. Williams Interactive fisheries governance, Delft: Eburon Publishers. 2005. 72 pp.

[53] D. Symes, Fisheries governance: a coming of age for fisheries social science. Fisheries Research. 81, 2006, 113-117.

[54] R. Mahon, P. McConney, R. Roy. Governing fisheries as complex adaptive systems. Marine Policy. 32, 2008, 104-112.

[55] X. Basurto, M. Nenadovic. A systematic approach to studying fisheries governance. Global Policy. 3(2), 2012, 222-230. 
[56] R. Pomeroy, R. Brainard, M. Moews, A. Heenan, J. Shackeroff, N. Armada. Coral Triangle Regional Ecosystem Approach to Fisheries Management (EAFM) Guidelines. Honolulu, Hawaii: The USAID Coral Triangle Support Partnership. 2013.

[57] R. Pomeroy, K. Hiew, K Ramdass, J. M Saad, P. Lokani, G Mayo-Anda, E. Lorenzo,G. Manero, Z. Maguad, M. Pido, G. Goby. Moving Towards an Ecosystem Approach to Fisheries Management in the Coral Triangle Region. Marine Policy. 51, 2015, 211-219

[58] R. S. Pomeroy, K. Viswanathan. Fisheries Co-management Developments in Southeast Asia and Bangladesh. In D.G. Wilson, J. Raakjaer-Nielsen and P. Degnbol (eds.) The Fisheries Comanagement Experience: Accomplishments, Challenges and Prospects. Dordrecht, The Netherlands: Kluwer Academic Publishers. 2003.

[59] A. Tawake, J. Parks, P. Radikedike, W. Aalbersberg, V. Vuki, N. Salafsky, Harvesting clams and data: involving local communities in monitoring: a case in Fiji. Cons. Biol. In Practice 2, 2001, 32-35.

[60] R. S. Pomeroy, J. Parks, R. Pollnac, T. Campson, E. Genio, C. Marlessy, E. Holle, M. Pido, A. Nissapa, S. Boromthanarat, N. T. Hue. Fish Wars: Conflict and Collaboration in Fisheries Management in Southeast Asia." Marine Policy. 31(6), 2007, 645-656.

[61] U. Muawanah, R. Pomeroy, C. Marlessy. Revisiting Fish Wars: Conflict and Collaboration over Fisheries in Indonesia. Coastal Management 40, 2012, 279-288

[62] R. S. Pomeroy, R. Rivera-Guieb. Fisheries co-management: a practical handbook. CAB International, Rome and International Development Research Centre, Ottawa, Canada. 2006.

[63] B. M. Katon, R.S. Pomeroy, L.R. Garces, A.M. Salamanca. Fisheries Management of San Salvador Island, Philippines: A Shared Responsibility. Society and Natural Resources. 12(8), 1998, 777-795

[64] R. Pomeroy, J. Parks, K. Courtney, P. Collier, N. Mattich. Southeast Asia Regional Fisheries Stakeholder Analysis: a study undertaken for USAID/RDMA. Bangkok: United States Agency for International Development - Regional Development Mission for Asia. 2014.

[65] OECD. Principle Elements of Good Governance. Organization for Economic Cooperation and Development, Paris, France. 2007. Available at: http://www.oecd.org/.

[66] US Department of State, US Department of Defense, USAID, US Department of Justice, US Department of Homeland Security, US Department of Transportation. Maritime Security Sector Reform. Washington DC. 2010. 45 pp. 


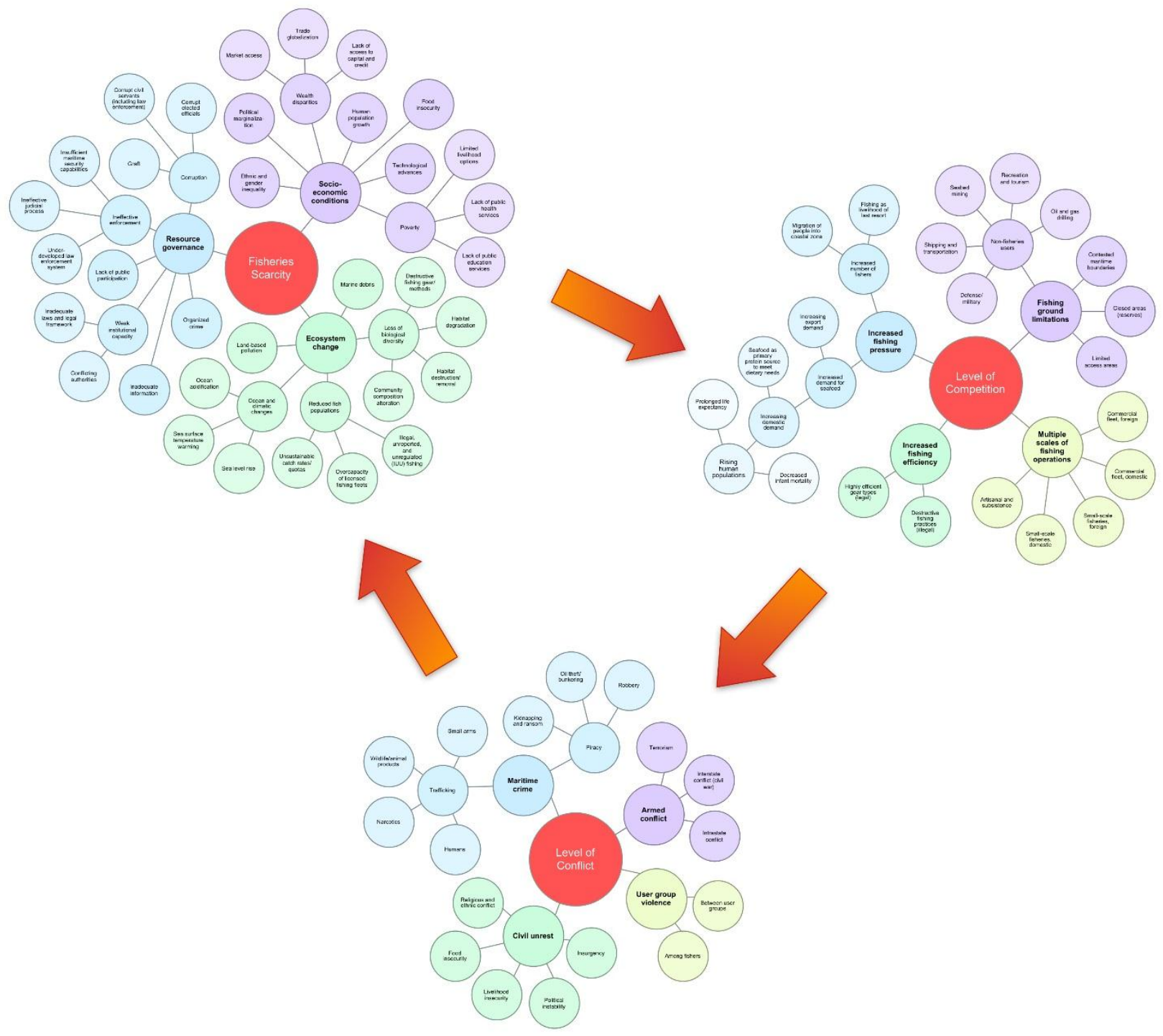

Figure 1. Fish wars cycle 


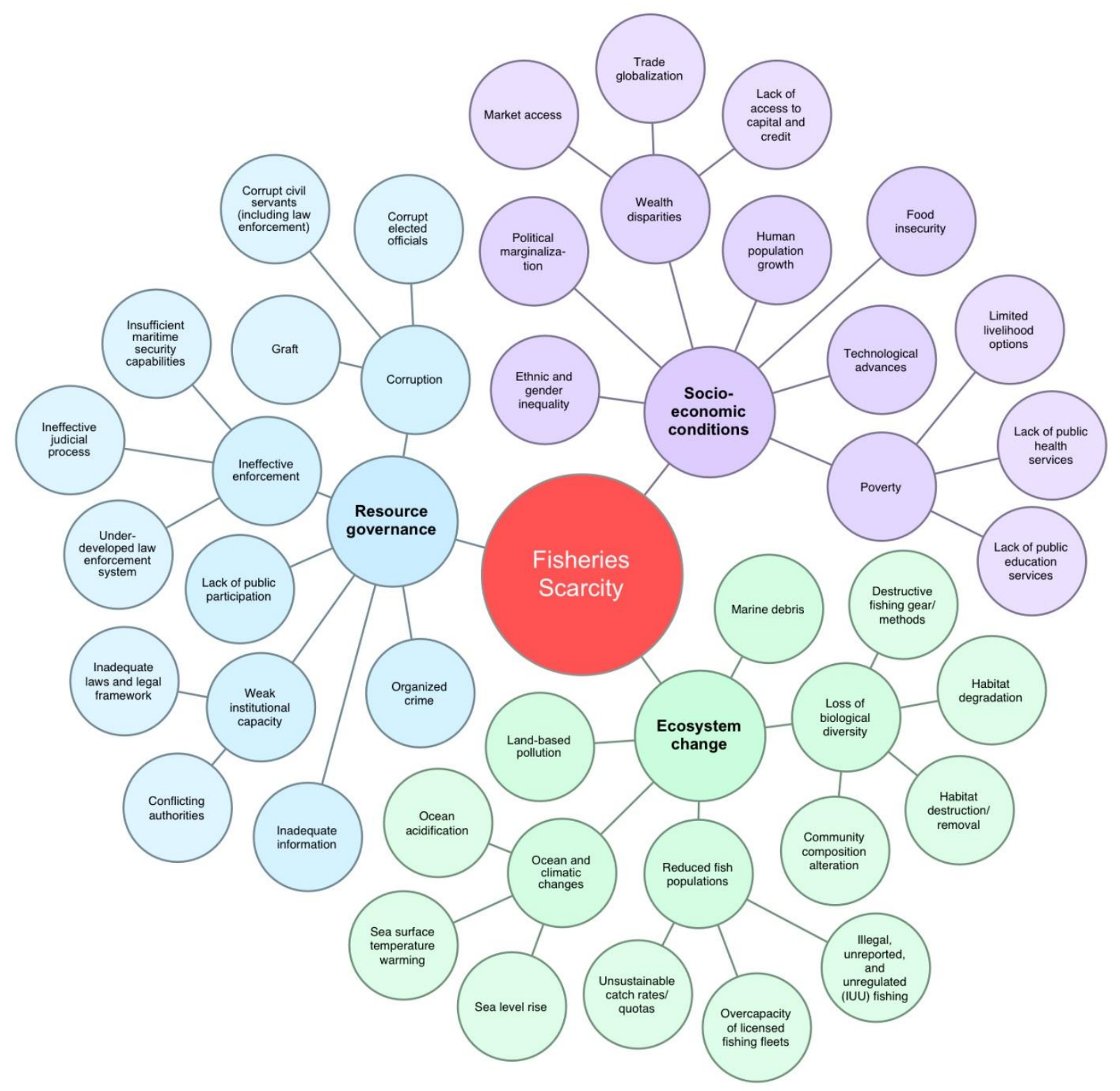

Figure 2. Fisheries scarcity 


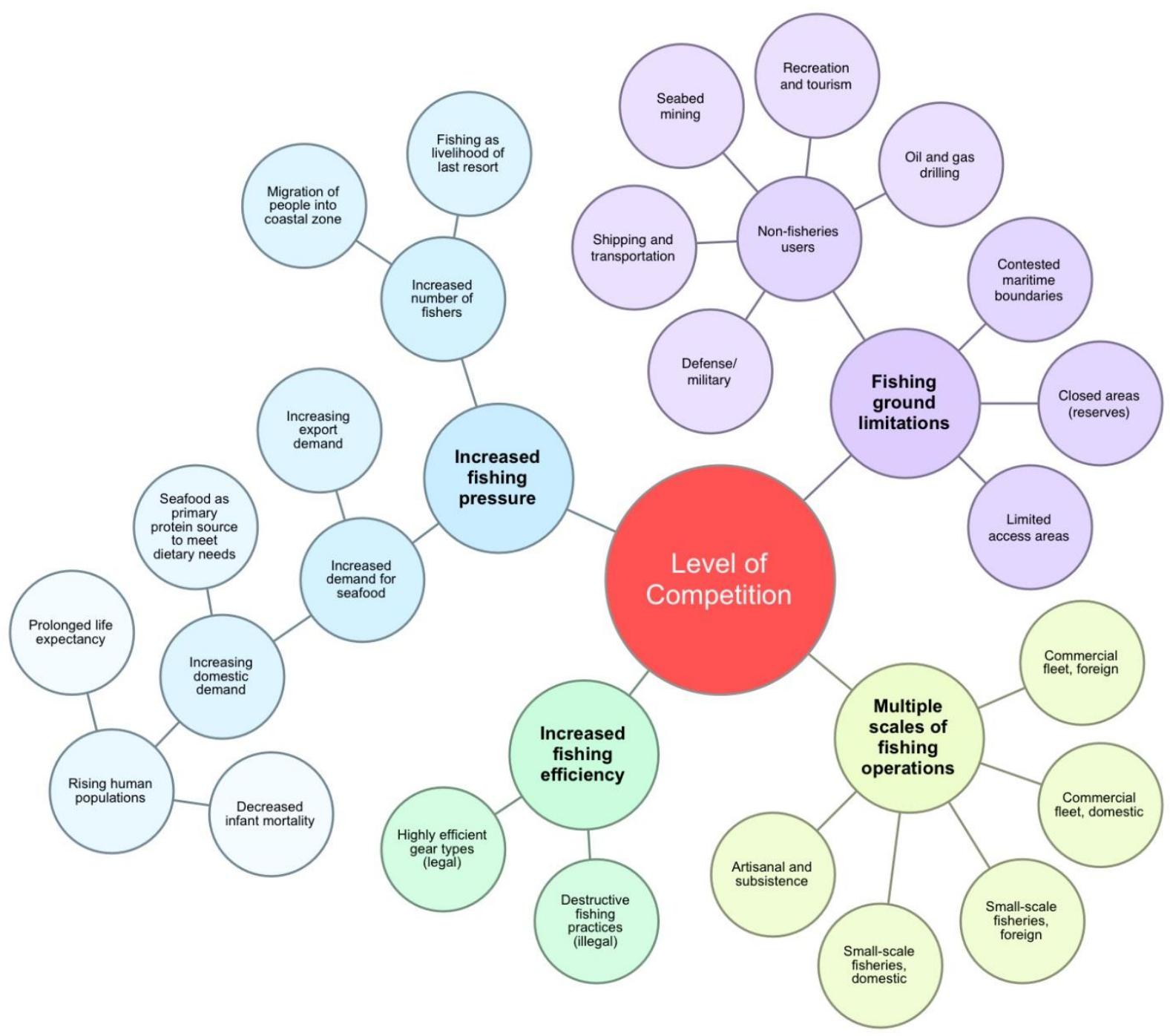

Figure 3. Level of competition 


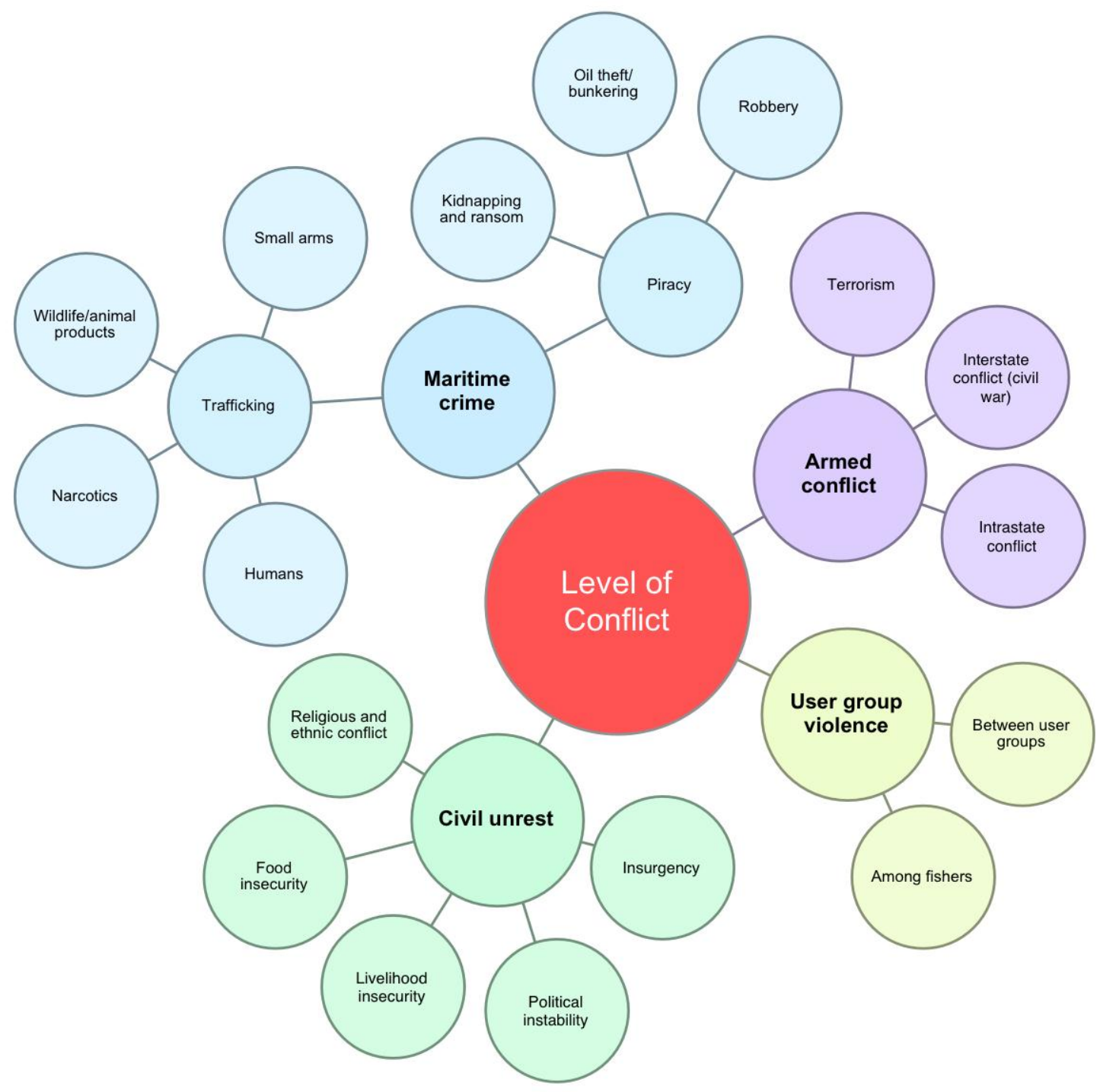

Figure 4. Level of conflict 
Table 1. Types of fisheries-related conflicts, with key associated drivers and examples.

\begin{tabular}{|c|c|c|}
\hline Conflict Type & Key Associated Drivers & Examples \\
\hline $\begin{array}{l}\text { Violence between } \\
\text { fishers operating } \\
\text { at the same scale }\end{array}$ & $\begin{array}{l}\text { - Shared, limited fishing } \\
\text { grounds } \\
\text { - Scale-specific fishing } \\
\text { restrictions } \\
\text { - Legal and illegal/destructive } \\
\text { fishing techniques used in } \\
\text { proximity } \\
\text { - Coastal crowding } \\
\text { - Human population growth } \\
\text { - Poverty } \\
\text { - Lack of participation }\end{array}$ & $\begin{array}{l}\text { - Restricted/closed areas limit available } \\
\text { fishing grounds by small-scale fishers } \\
\text { - Explosives fishing conducted by local } \\
\text { fishers in same area locals use legal } \\
\text { nets } \\
\text { - Entry of more fishers into target } \\
\text { fishery than can operate sustainably, } \\
\text { as a livelihood of last resort }\end{array}$ \\
\hline $\begin{array}{l}\text { Violence among } \\
\text { fishers operating } \\
\text { at different scales }\end{array}$ & $\begin{array}{l}\text { - Overlapping fishing grounds } \\
\text { - Competing gear types, within } \\
\text { the water column } \\
\text { - Competing gear types, on the } \\
\text { sea floor } \\
\text { - Overcapacity } \\
\text { - Increasing seafood demand } \\
\text { by consumers } \\
\text { - Globalized markets and trade } \\
\text { - Weak enforcement }\end{array}$ & $\begin{array}{l}\text { - Domestic purse seiner deliberately } \\
\text { running over and destroying nets laid } \\
\text { by small-scale fishers operating in } \\
\text { same area } \\
\text { - Foreign trawlers navigating } \\
\text { aggressively toward or colliding with } \\
\text { artisanal fishers } \\
\text { - Small-scale fishers firing upon } \\
\text { licensed foreign commercial operators } \\
\text { - Rising cost of local seafood products } \\
\text { - Increasing market pressure on fishers } \\
\text { to land more seafood products }\end{array}$ \\
\hline $\begin{array}{l}\text { Maritime crime } \\
\text { - Trafficking } \\
\text { - Smuggling } \\
\text { - Piracy (robbery } \\
\text { at sea) } \\
\text { - Kidnapping and } \\
\text { ransom } \\
\text { - Illegal, } \\
\text { unreported and }\end{array}$ & $\begin{array}{l}\text { - Poverty } \\
\text { - Limited livelihood options } \\
\text { - Overfishing } \\
\text { - Food insecurity } \\
\text { - Wealth disparities } \\
\text { - Corruption }\end{array}$ & $\begin{array}{l}\text { - Smuggling of narcotics or wildlife } \\
\text { products } \\
\text { - Forced labor of foreign nationals } \\
\text { onboard commercial fishing vessels } \\
\text { - Commercial fishing vessel forcibly } \\
\text { boarded and stolen at sea; crew set } \\
\text { adrift } \\
\text { - Payment negotiated for release of } \\
\text { commercial fishing crew by captors }\end{array}$ \\
\hline
\end{tabular}




\begin{tabular}{|c|c|c|}
\hline $\begin{array}{l}\text { unregulated } \\
\text { fishing }\end{array}$ & & \\
\hline $\begin{array}{l}\text { Armed conflict } \\
\text { - Insurgency } \\
\text { - Interstate } \\
\text { conflict } \\
\text { - Terrorism }\end{array}$ & $\begin{array}{l}\text { - Political marginalization } \\
\text { - Poverty } \\
\text { - Limited livelihood options } \\
\text { - Overfishing } \\
\text { - Food insecurity } \\
\text { - Wealth disparities } \\
\text { - Political instability }\end{array}$ & $\begin{array}{l}\text { - Conscription of artisanal fishers to } \\
\text { transport militia groups and small } \\
\text { arms } \\
\text { - Fishers attacked by neighboring } \\
\text { foreign coast guard/navy vessels } \\
\text { during war } \\
\text { - Fish catch forcibly surrendered to } \\
\text { occupying force to feed troops } \\
\text { - Fishers executed at sea by ideological } \\
\text { extremists }\end{array}$ \\
\hline Civil unrest & $\begin{array}{l}\text { - Food insecurity } \\
\text { - Religious, racial and ethnic } \\
\text { diversity } \\
\text { - Livelihood and economic } \\
\text { insecurity } \\
\text { - Political instability }\end{array}$ & $\begin{array}{l}\text { - Catch forcibly taken from fishers } \\
\text { - Ethnic cleansing in coastal } \\
\text { communities } \\
\text { - Rioting, public protests, looting } \\
\text { - Coup d'état }\end{array}$ \\
\hline
\end{tabular}

